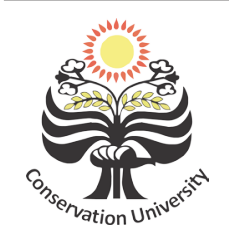

\title{
Pengembangan Perangkat Pembelajaran Filsafat Matematika melalui Pembelajaran Kooperatif Tipe STAD dengan Strategi Berbasis Kompetensi dan Konservasi
}

\author{
Hardi Suyitno' dan Rochmad ${ }^{2}$
}

\author{
1,2 Jurusan Matematika, Fakultas Matematika dan Ilmu Pengetahuan Alam, \\ Universitas Negeri Semarang, Kampus Sekaran, Kel. Sekaran, Kec. Gunung Pati, \\ Jawa Tengah 50229, Indonesia +6224 8508093 \\ Email: 'hhardisunnes@yahoo.com, ${ }^{2}$ robinbamanden@gmail.com
}

DOI: http://dx.doi.org/10.15294/kreano.v6i2.4981

Received : August 2015; Accepted: September 2015; Published: December 2015

\begin{abstract}
Abstrak
Penelitian ini bertujuan untuk mengembangkan perangkat pembelajaran Filsafat Matematika melalui pembelajaran kooperatif tipe STAD dengan strategi berbasis kompetensi dan konservasi. Perangkat dikembangkan menggunakan model 4-D yang dicetuskan oleh Thiagarajan, Semmel, \& Semmel. Dari segi validitas, silabus yang dikembangkan memperoleh skor kevalidan 86.11, SAP yang dikembangkan memperoleh skor kevalidan 89.58, kontrak perkuliahan yang dikembangkan memperoleh skor kevalidan 86.81, lembar kerja mahasiswa yang dikembangkan memperoleh skor kevalidan 86.81. Sementara dari segi kepraktisan, hasil pengamatan keterlaksanaan pembelajaran mendapatkan skor 91.00, serta respon positif mahasiswa terhadap semua aspek berada di atas 50\%. Dari segi keefektifan, diperoleh hasil bahwa nilai rata-rata hasil tes pertama dan kedua meningkat dari 84.43 menjadi 94.49. Hasil tersebut menunjukkan bahwa perangkat pembelajaran Filsafat Matematika yang dikembangkan bersifat valid, praktis, dan efektif.
\end{abstract}

\begin{abstract}
This research aims to develop a learning tools of Philosophy of Mathematics through STAD cooperative learning with the competency-based and conservation-based strategies. We develop the learning tools using 4-D models developed by Thiagarajan, Semmel, \& Semmel. In terms of validity, the syllabus obtain a score of validity 86.11, lesson plan obtain a score of validity 89.58, lectures contract obtain a score of validity 86.81, and student worksheets obtain a score of validity 86.81. In terms of practicality, observation of feasibility study get a score of 91.00 , and we get more then $50 \%$ of positive response for all aspects in a questionnaire filled out by students. In terms of effectiveness, the average value of the first and the second test results increase of 84.43 into 94.49. These results suggest that the learning tools developed are valid, practical, and effective.
\end{abstract}

Keywords: development, learning tools, philosophy of mathematics, STAD

\section{PENDAHULUAN}

Unnes menerapkan kurikulum berbasis kompetensi dan konservasi sejak Universitas Konservasi dicanangkan pada tanggal 10 Maret 2010 dan dikuatkan lewat Permendiknas Nomor 8 Tahun 2011 tentang Statuta UNNES. Dalam rangka mewujudkan Universitas Konservasi, proses perkuliahan yang merupakan representasi dari pendidikan dan pengajaran diharapkan mencetak lulusan yang memiliki ketercapaian penguasaan kompetensi aka- demik sekaligus memberikan jaminan tumbuhnya nilai-nilai karakter dan berbasis nilainilai konservasi. Nilai-nilai karakter konservasi (religius, jujur, cerdas, adil, tanggung jawab, peduli, toleran, demokratis, cinta tanah air, tangguh, dan santun) diupayakan agar dapat dipelajari oleh mahasiswa pada setiap proses perkuliahan.

Filsafat Matematika merupakan salah satu mata kuliah di perguruan tinggi yang diajarkan di Program Studi S1 Pendidikan 
Matematika Jurusan Matematika Fakultas Matematika dan Ilmu Pengetahuan Alam Universitas Negeri Semarang. Mata kuliah ini merupakan bentuk spesifik dari kajian Filsafat Ilmu. Selayaknya Filsafat IImu, Filsafat Matematika menjelaskan hakekat ilmu matematika yang mempunyai banyak keterbatasan, sehingga dapat diperoleh pemahaman yang padu mengenai berbagai fenomena alam yang telah menjadi objek matematika itu sendiri dan yang cenderung terfragmentasi. Di sini Filsafat Matematika bermanfaat dalam (1) melatih mahasiswa berfikir radikal tentang hakekat matematika, (2) melatih berfikir reflektif di dalam lingkup ilmu matematika, (3) menghindarkan diri dari memutlakan kebenaran ilmiah, dan menganggap bahwa matematika sebagai satu-satunya cara memperoleh kebenaran, (4) menghidarkan diri dari egoisme ilmiah, yakni tidak menghargai sudut pandang lain di luar bidang matematika (Suharsaputra, 2004).

Filsafat matematika adalah bagian dari filsafat yang berbicara tentang matematika dan mengkaji asumsi-asumsi, landasan, dan implikasi matematika secara filosofis (Hers, 1997). Filsafat matematika memberikan suatu pertanggungjawaban berkaitan dengan hakikat dan metodologi matematika dalam kehidupan manusia (Suyitno, 2014). Begitu pentingnya filsafat matematika dikuasai oleh mahasiswa sehingga nanti ketika mahasiswa sudah menjadi guru, ia dapat menyampaikan materi matematika secara komprehensif.

Filsafat Matematika sendiri merupakan bentuk spesifik dari epistemologi (yang secara umum membahas asal pengetahuan dan bagaimana pengetahuan manusia dibentuk), dimana Filsafat Matematika membahas asal matematika dan bagaimana suatu sistem ilmu matematika dibentuk. Filsafat Matematika memiliki fungsi teramat penting, yakni memberi fondasi yang kuat dan sistematis pada pengetahuan dan kebenaran metematika (Ernest, 1991). Sebagai konsekuensinya, mahasiswa yang gagal dalam mata kuliah Filsafat Matematika akan kesulitan dalam memaknai hakikat matematika secara komprehensif.

Materi Filsafat Matematika termasuk materi yang berkembang secara dinamis seiring kemajuan matematika itu sendiri. Di samping perubahan materi, perlu pula dilakukan revisi secara berkala terkait teknik penyajian mata kuliah tersebut, misalnya dengan pendekatan konstruktivisme. Salah satu model pembelajaran yang menggunakan pendekatan konstruktivisme ialah pembelajaran kooperatif (Nykos \& Hashimoto, 1997) (Jones \& Brader-Araje, 2002). Pembelajaran kooperatif dapat digunakan untuk melibatkan mahasiswa secara aktif dalam proses pembelajaran. Ada banyak penelitian yang menunjukkan bahwa suasana belajar kooperatif menghasilkan prestasi yang lebih tinggi, hubungan yang lebih positif, dan penyesuaian psikologis yang lebih baik daripada suasana belajar yang penuh persaingan dan memisah-misahkan mahasiswa (Johnson, Johnson, \& Smith, 1989). Menurut beberapa hasil penelitian pembelajaran kooperatif dapat diterapkan di Indonesia dengan hasil dapat meningkatkan prestasi belajar mahasiswa, membangkitkan mahasiswa aktif belajar, dan suasana kelas yang menyenangkan (Sulistyorini, 1998).

Salah satu tipe pembelajaran kooperatif adalah Student Teams Achievment Devisions (STAD). Pembelajaran kooperatif tipe STAD dicirikan oleh suatu struktur tugas, tujuan dan penghargaan kooperatif. Mahasiswa bekerja sama dalam situasi semangat pembelajaran kooperatif seperti membutuhkan kerja sama untuk mencapai tujuan bersama dan mengkoordinasikan usahanya untuk menyelesaikan tugas. Berdasar uraian tersebut, peneliti tertarik untuk mengembangkan perangkat pembelajaran Filsafat Matematika melalui pembelajaran kooperatif tipe STAD dengan strategi berbasis kompetensi dan konservasi.

\section{METODE}

Penelitian ini merupakan penelitian pengembangan. Produk yang dikembangkan dan diuji cobakan dalam penelitian ini adalah perangkat pembelajaran Filsafat Matematika melalui pembelajaran kooperatif tipe STAD dengan strategi berbasis kompetensi dan konservasi.

Perangkat dikembangkan menggunakan model 4-D yang dicetuskan oleh Thiagarajan, Semmel, \& Semmel (1974). Pengembangan perangkat menggunakan model ini akan melewati empat tahap, yakni (1) define (pendefinisian), (2) design (perancangan), (3) 
Tabel 2. Sintaks pembelajaran kooperatif tipe STAD dengan strategi berbasis kompetensi dan konservasi

\begin{tabular}{|c|c|c|c|c|}
\hline No & Fase & Indikator & Aktivitas Guru & Nilai konservasi \\
\hline \multirow[t]{3}{*}{1} & \multirow[t]{3}{*}{$\begin{array}{l}\text { Presentasi } \\
\text { kelas }\end{array}$} & Membuka pelajaran & $\begin{array}{l}\text { Dosen mengawali pembelajaran } \\
\text { dengan berdoa }\end{array}$ & Nilai religius \\
\hline & & $\begin{array}{l}\text { Menyampaikan tu- } \\
\text { juan dan memotivasi } \\
\text { siswa }\end{array}$ & $\begin{array}{l}\text { Dosen menyampaikan tujuan pem- } \\
\text { belajaran yang ingin dicapai pada } \\
\text { pembelajaran tersebut dan memoti- } \\
\text { vasi mahasiswa }\end{array}$ & $\begin{array}{l}\text { Nilai tangguh dan } \\
\text { cinta tanah air }\end{array}$ \\
\hline & & $\begin{array}{l}\text { Menyajikan materi } \\
\text { pelajaran }\end{array}$ & $\begin{array}{l}\text { Menyajikan materi pembelajaran } \\
\text { kepada mahasiswa dengan jalan } \\
\text { demonstrasi, melalui bahan ajar atau } \\
\text { media pembelajaran }\end{array}$ & $\begin{array}{l}\text { Nilai cerdas dan } \\
\text { demokratis }\end{array}$ \\
\hline \multirow[t]{2}{*}{2} & \multirow[t]{2}{*}{ Tim } & $\begin{array}{l}\text { Mengorganisasikan } \\
\text { siswa ke dalam ke- } \\
\text { lompok kooperatif }\end{array}$ & $\begin{array}{l}\text { Mengelompokkan mahasiswa terdiri } \\
\text { dari 4-5 orang tiap kelompok }\end{array}$ & Nilai toleran \\
\hline & & $\begin{array}{l}\text { Membimbing ke- } \\
\text { lompok bekerja dan } \\
\text { belajar }\end{array}$ & $\begin{array}{l}\text { Membimbing kelompok-kelompok } \\
\text { belajar pada saat mereka menger- } \\
\text { jakan tugas mereka }\end{array}$ & $\begin{array}{l}\text { Nilai demokra- } \\
\text { tis, toleran, dan } \\
\text { peduli }\end{array}$ \\
\hline 3 & Kuis & \multirow[t]{2}{*}{ Evaluasi } & Mengevaluasi hasil belajar tentang & \multirow{2}{*}{$\begin{array}{l}\text { Nilai toleran, adil, } \\
\text { santun, dan peduli }\end{array}$} \\
\hline 4 & $\begin{array}{l}\text { Skor kema- } \\
\text { juan individu }\end{array}$ & & $\begin{array}{l}\text { materi yang telah dipelajari dengan } \\
\text { kuis individual atau masing-masing } \\
\text { kelompok mempresentasikan hasil } \\
\text { kerjanya. Pada saat pemaparan hasil } \\
\text { diskusi kelompok, kelompok lain } \\
\text { dapat memberikan pendapat. Setiap } \\
\text { kelompok melakukan presentasi } \\
\text { secara bergantian }\end{array}$ & \\
\hline 5 & Rekognisi tim & \multirow{2}{*}{$\begin{array}{l}\text { Memberikan peng- } \\
\text { hargaan }\end{array}$} & Memberikan penghargaan kepada & \multirow{2}{*}{$\begin{array}{l}\text { Nilai toleran, } \\
\text { cerdas }\end{array}$} \\
\hline 6 & $\begin{array}{l}\text { Penghargaan } \\
\text { Kelompok }\end{array}$ & & $\begin{array}{l}\text { setiap kelompok berdasarkan dari } \\
\text { prestasi yang diperoleh masing-mas- } \\
\text { ing kelompok }\end{array}$ & \\
\hline
\end{tabular}

develop (pengembangan), dan (4) desseminate (penyebaran). Pada penelitian ini, model 4-D dibatasi sampai tahap ketiga yakni tahap develop (pengembangan). Tahap define meliputi lima fase: (a) front-end analysis; (b) learner analysis; (c) task analysis; (d) concept analysis; dan (e) specifying instructional objectives. Tahap design terdiri dari empat fase: (a) constructing criterion-referenced test; (b) media selection; (c) format selection; dan (d) initial design. Tahap develop meliputi dua fase: (a) expert appraisal; dan (b) developmental testing.

Instrumen yang digunakan adalah lembar validasi untuk memperoleh data tentang hasil validasi para ahli mengenai perangkat pembelajaran, lembar pengamatan untuk memperoleh data pengamatan aktivitas mahasiswa dalam melaksanakan kegiatan-ke- giatan diskusi kelompok, dan angket respon mahasiswa terhadap kegiatan praktik penggunaan perangkat pembelajaran mata kuliah Filsafat Matematika.

Perangkat pembelajaran yang dikembangkan dalam penelitian ini menggambarkan proses pembelajaran Filsafat Matematika menggunakan pembelajaran kooperatif tipe STAD dengan strategi berbasis kompetensi dan konservasi yang memuat sintaks sebagai berikut.

\section{PEMBAHASAN}

Tahap define terdiri dari (a) front-end analysis; (b) learner analysis; (c) task analysis; (d) concept analysis; dan (e) specifying instructional objectives. Dari kelima langkah tersebut, diturunkan capaian pembelajaran atau kompetensi mata kuliah Filsafat Matemati- 
ka. Secara umum, tujuan diberikannya mata kuliah Filsafat Matematika adalah harapan agar mahasiswa mampu berpikir logis, kritis, kreatif, dan inovatif. Kemampuan umum tersebut diturunkan lagi dalam kemampuan-kemampuan teknis yaitu mahasiswa mampu (1) menjelaskan pengertian filsafat, (2) menjelaskan pentingnya filsafat bagi matematika, (3) menjelaskan pengertian logika dan konsepkonsep yang termuat dalam logika, (4) menjelaskan hakikat matematika, (5) menjelaskan hubungan bahasa, logika, dan matematika, (6) menjelaskan hubungan matematika dan realitas dunia, (7) menjelaskan aliran pokok dalam filsafat matematika, (8) menjelaskan garis besar sejarah matematika, dan (9) menyebutkan beberapa matematikawan, filosof matematika, dan karyanya.

Format perangkat pembelajaran mengacu pada ketentuan yang berlaku di Unnes, sekaligus tetap memuat pembelajaran kooperatif tipe STAD dan berbasis karakter konservasi. Perangkat yang dirancang adalah (1) Silabus, (2) Satuan Acara Perkuliahan, (3) Kontrak Perkuliahan, (4) Lembar Kerja Mahasiswa, dan (5) Instrumen Penilaian.

Hasil fase realisasi/konstruksi adalah dihasilkannya perangkat yang telah didesain. Silabus memuat deskripsi mata kuliah, capaian pembelajaran/kompetensi matakuliah, prasyarat, capaian pembelajaran/kompetensi, indikator, materi, kegiatan pembelajaran, penilaian, alokasi waktu dan sumber belajar. Kegiatan pembelajaran juga disesuaikan dengan model pembelajaran kooperatif tipe STAD. Selain itu pada silabus diintegrasikan nilai karakter pada setiap kegiatan pembelajarannya.

Satuan Acara Perkuliahan memuat capaian pembelajaran/kompetensi mata kuliah, capaian pembelajaran/kompetensi, indikator capaian pembelajaran/ kompetensi, tujuan pembelajaran, materi pokok, metode pembelajaran, langkah pembelajaran (mengacu pada sintaks pembelajaran STAD), alat, media, dan sumber belajar, penilaian. Satuan acara perkuliahan yang dikembangkkan terdiri dari 16 SAP. Kontrak perkuliahan dikembangkan dengan memuat deskripsi mata kuliah, manfaat, tugas, penilaian, bobot penilaian, jadwal perkuliahan setiap minggunya, dan sumber belajar. Tes yang dikembangkan pada peneli- tian ini ada 2 tes; tes 1 diwujudkan dalam bentuk UTS, dan tes 2 diwujudkan dalam bentuk UAS.

Selanjutnya akan dijelaskan hasil fase pengujian, evaluasi, dan revisi hasil. Hasil validasi silabus, SAP, kontrak, dan LKM ditunjukkan pada Tabel 3, Tabel 4, Tabel 5, dan Tabel 6.

Tabel 3. Hasil Validasi Silabus

\begin{tabular}{|c|c|c|}
\hline & $\begin{array}{c}\text { Hasil validasi } \\
\text { silabus }\end{array}$ & Kategori \\
\hline Validator 1 & $87.50 \%$ & Baik \\
\hline Validator 2 & $84.72 \%$ & Baik \\
\hline \multicolumn{3}{|c|}{ Tabel 4. Hasil Validasi SAP } \\
\hline & Hasil validasi SAP & Kategori \\
\hline Validator 1 & $91.67 \%$ & Baik \\
\hline Validator 2 & $87.50 \%$ & Baik \\
\hline
\end{tabular}

Tabel 5. Hasil Validasi Kontrak Perkuliahan

\begin{tabular}{lcl}
\hline & $\begin{array}{c}\text { Hasil validasi kontrak } \\
\text { perkuliahan }\end{array}$ & Kategori \\
\hline Validator 1 & $83.33 \%$ & Baik \\
Validator 2 & $90.28 \%$ & Baik \\
\hline
\end{tabular}

Tabel 6. Hasil Validasi Lembar Kerja Mahasiswa

\begin{tabular}{lcl}
\hline & $\begin{array}{c}\text { Hasil validasi } \\
\text { angket }\end{array}$ & Kategori \\
\hline Validator 1 & $91.67 \%$ & Baik \\
Validator 2 & $94.44 \%$ & Baik \\
\hline
\end{tabular}

Penilaian komponen silabus, SAP, kontrak perkuliahan, dan LKM meliputi isi dan konstruksi bahasa. Adapun kriteria valid ditunjukkan sebagai berikut.

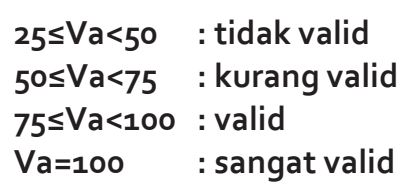

Dengan Va adalah rata-rata hasil validasi ahli

Hasil validasi silabus kedua validator adalah 87.50 dan 84.72 , dimana jika diratarata akan didapatkan hasil 86.11 di mana angka tersebut menunjukkan bahwa silabus valid digunakan. Hasil validasi SAP kedua validator adalah 91.67 dan 87.50, dimana jika diratarata akan didapatkan hasil 89.58. Angka ini menunjukkan bahwa SAP sudah valid. Hasil validasi kontrak perkuliahan kedua validator 
adalah 83.33 dan 90.28, dimana jika diratarata akan didapatkan hasil 86.81. Angka ini menunjukkan bahwa kontrak perkuliahan sudah valid. Hasil validasi lembar kerja mahasiswa kedua validator adalah 83.33 dan 90.28, dimana jika dirata-rata akan didapatkan hasil 86.81. Angka ini menunjukkan bahwa lembar kerja mahasiswa sudah valid.

Selanjutnya dilakukan uji coba di lapangan untuk menilai kepraktisan dan keefektifan dari perangkat yang dikembangkan. Kepraktisan memuat keterlaksanaan pembelajaran (Tabel 7) dan respon mahasiswa (Tabel 8). Sementara keefektifan memuat hasil tes siklus pertama dan kedua.

Tabel 7. Hasil Pengamatan Keterlaksanaan Pembelajaran

\begin{tabular}{ccc}
\hline $\begin{array}{c}\text { Keterlaksanaan } \\
\text { Pembelajaran }\end{array}$ & Persentase & Kategori \\
\hline Siklus 1 & $88.00 \%$ & Baik \\
Siklus 2 & $94.00 \%$ & Baik \\
\hline Rata-rata & $91.00 \%$ & Baik \\
\hline
\end{tabular}

Kedua persentase tersebut mendapatkan rata-rata hasil pengamatan yaitu $91.00 \%$ sehingga dapat ditarik kesimpulan kemampuan dosen dalam mengelola pembelajaran dalam kategori baik, dengan menggunakan acuan sebagai berikut.

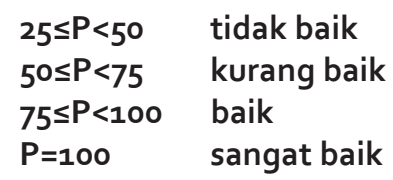

Dengan adalah rata-rata hasil pengamatan

Dengan demikian, perangkat pembelajaran dapat digunakan dengan baik dalam proses pembelajaran.

Angket respon mahasiswa yang diisi oleh 34 mahasiswa setelah mengikuti pembelajaran dengan perangkat pembelajaran Filsafat Matematika. Rincian hasil angket respon mahasiswa tersebut dapat dilihat pada Tabel 8.

Berdasarkan tabel di atas, dapat dianalisa bahwa respon positif mahasiswa terhadap semua aspek berada di atas 50\% yang berarti setiap aspek direspon positif oleh mahasiswa lebih dari 50\%. Berdasarkan pada kriteria kepraktisan bahwa perangkat yang dikembangkan telah dapat mewujudkan keterlaksanaan pembelajaran dan direspon positif oleh mahasiswa, sehingga disimpulkan bahwa perangkat dapat digunakan. Selanjutnya dibahas hasil penelitian dalam hal keefektifan, yang dalam hal ini memuat hasil tes siklus pertama

Tabel 8. Hasil Angket Respon Mahasiswa

\begin{tabular}{|c|c|c|c|}
\hline \multirow{2}{*}{ No. } & \multirow{2}{*}{ Aspek yang direspon } & \multicolumn{2}{|c|}{ Persentase Respon Mahasiswa } \\
\hline & & Positif & Negatif \\
\hline \multirow[t]{5}{*}{1} & Perasaan senang terhadap komponen pembelajaran & & \\
\hline & a. Cara mengajar dosen & $91.89 \%$ & $8.11 \%$ \\
\hline & b. Suasana pembelajaran di kelas & $86.49 \%$ & $13 \cdot 51 \%$ \\
\hline & c. Materi pembelajaran & $83.78 \%$ & $16.22 \%$ \\
\hline & d. Strategi pembelajaran & $94.59 \%$ & $5.41 \%$ \\
\hline \multirow[t]{5}{*}{2} & Kebaruan komponen pembelajaran ini & & \\
\hline & a. Cara mengajar dosen & $75.68 \%$ & $24 \cdot 32 \%$ \\
\hline & b. Suasana pembelajaran di kelas & $78.38 \%$ & $21.62 \%$ \\
\hline & c. Materi pembelajaran & $83.78 \%$ & $16.22 \%$ \\
\hline & d. Strategi pembelajaran & $83.78 \%$ & $16.22 \%$ \\
\hline 3 & $\begin{array}{l}\text { Adanya minat mengikuti pembelajaran mata kuliah lain den- } \\
\text { gan cara seperti diikuti pada mata kuliah Filsafat Matematika }\end{array}$ & $91.89 \%$ & $8.11 \%$ \\
\hline 4 & Pemahaman materi yang diajarkan & $86.49 \%$ & $13.51 \%$ \\
\hline 5 & $\begin{array}{l}\text { Pembelajaran kooperatif tipe STAD dapat terlaksana dalam } \\
\text { pembelajaran }\end{array}$ & $91.89 \%$ & $8.11 \%$ \\
\hline 6 & $\begin{array}{l}\text { Karakter konservasi dapat diinternalisasikan dalam pembela- } \\
\text { jaran }\end{array}$ & $86.49 \%$ & $13.51 \%$ \\
\hline
\end{tabular}


(Tabel 9) dan kedua (Tabel 10).

Tabel 9. Hasil Tes Pertama

\begin{tabular}{ccc}
\hline No & Uraian & Hasil Tes \\
\hline 1 & Nilai terendah & 70 \\
2 & Nilai tertinggi & 98 \\
\hline 3 & Rata-rata & 84.43 \\
\hline
\end{tabular}

Berdasarkan tabel terlihat bahwa nilai terendahnya adalah 70 , nilai tertinggi 98 , dan nilai rata-ratanya adalah 84,43 .

Tabel 10. Hasil Tes Kedua

\begin{tabular}{ccc}
\hline No & Uraian & Hasil Tes \\
\hline 1 & Nilai terendah & 84 \\
2 & Nilai tertinggi & 100 \\
\hline 3 & Rata-rata & 94.49 \\
\hline
\end{tabular}

Berdasarkan tabel terlihat bahwa nilai terendahnya adalah 84, nilai tertinggi 100, dan nilai rata-ratanya adalah 94.49.

Salah satu indikator yang menunjukkan bahwa perangkat pembelajaran yang dikembangkan tersebut efektif adalah adanya peningkatan prestasi mahasiswa. Nilai rata-rata hasil tes pertama dan kedua berturut-turut adalah 84.43 dan 94.49. Terlihat bahwa ada peningkatan rata-rata hasil tes mahasiswa sehingga dapat dikatakan bahwa terdapat peningkatan kemampuan mahasiswa. Ini berbanding lurus dengan pendapat para ahli (Suminar, 2011) (Marwanto, 2008) (Hamzah, 2008) bahwa pembelajaran tipe STAD dapat meningkatkan prestasi dan kemampuan peserta didik. Dengan STAD, mahasiswa dituntut untuk lebih aktif dan berkontribusi dalam membangun konsep mereka sendiri. Ini berakibat pada kemampuan mahasiswa yang meningkat dibandingkan ketika mahasiswa dalam keadaan pasif dan cenderung "menerima" pengetahuan dari dosen.

Salah satu indikator yang menyatakan bahwa perangkat pembelajaran yang dikembangkan efektif adalah lebih dari 50\% siswa memberi respon positif terhadap perangkat pembelajaran. Respon yang dianalisis adalah (1) perasaan senang terhadap komponen pembelajaran, (2) Kebaruan komponen pembelajaran, (3) keberminatan mengikuti pembelajaran mata kuliah lain dengan cara seperti diikuti pada mata kuliah Filsafat Matematika, (4) kejelasan bahasa dan pemahaman materi yang diajarkan, (5) keterlakasanaan pembela- jaran kooperatif tipe STAD dalam pembelajaran, (6) diinternalisasikan karakter konservasi dalam pembelajaran. Keseluruhan item tersebut mendapatkan respon positif di atas 50\%, sehingga disimpulkan bahwa mayoritas siswa memberikan respon positif dan menganggap perangkat yang dikembangakn masuk dalam kategori baik.

Perangkat pembelajaran dikatakan efektif jika tujuan pembelajaran yang diharapkan tercapai (Khabibah, 2006). Data untuk keefektifan diperoleh dengan melihat tercapai atau tidaknya tujuan pembelajaran yang diharapkan. Indikator yang menyatakan bahwa perangkat pembelajaran yang efektif adalah (1) adanya peningkatan prestasi dan kemampuan mahasiswa, (2) lebih dari 50\% mahasiswa memberi respon positif terhadap perangkat pembelajaran. Berdasarkan analisis terhadap hasil uji coba, didapatkan fakta bahwa terdapat peningkatan prestasi dan kemampuan mahasiswa dan lebih dari 50\% mahasiswa memberi respon positif terhadap perangkat pembelajaran. Dari sini dapat dikatakan bahwa keefektifan perangkat terpenuhi.

Dari analisis hasil uji coba, perangkat pembelajaran yang dikembangkan telah memenuhi aspek keefetifan dan kepraktisan. Jadi telah didapatkan Pengembangan Perangkat Pembelajaran Filsafat Matematika Melalui Pembelajaran Kooperatif Tipe STAD dengan Strategi Berbasis Kompetensi dan Konservasi yang memenuhi kriteria valid, praktis, dan efektif. Jadi tujuan dari penelitian ini telah tercapai.

Menurut Nieveen (van den Akker, Branch, Gustafson, Nieveen, \& Plomp, 1999) suatu material berkualitas jika memenuhi aspek-aspek kualitas antara lain (1) validitas (validity), (2) kepraktisan (practicality), (3) keefektifan (effectiveness). Karena perangkat pembelajaran yang dikembangkan telah memenuhi kriteria valid, praktis, dan efektif, maka perangkat tersebut dikatakan berkualitas.

\section{SIMPULAN}

Pengembangan perangkat pembelajaran Filsafat Matematika melalui pembelajaran kooperatif tipe STAD dengan strategi berba- 
sis kompetensi dan konservasi menggunakan langkah-langkah (1) define (pendefinisian), (2) design (perancangan), (3) develop (pengembangan). Perangkat yang dikembangkan meliputi (1) silabus, (2) satuan acara perkuliahan, (3) kontrak perkuliahan, (4) lembar kerja mahasiswa, (5) instrumen penilaian (tes).

Melalui pengembangan perangkat pembelajaran Filsafat Matematika melalui pembelajaran kooperatif tipe STAD dengan strategi berbasis kompetensi dan konservasi diperoleh perangkat yang valid. Silabus memperoleh skor kevalidan 86.11, SAP memperoleh skor kevalidan 89.58. Kontrak perkuliahan memperoleh skor kevalidan 86.81. Lembar kerja mahasiswa kedua memperoleh skor kevalidan 86.81 . Disamping valid, uji coba yang dilakukan menunjukkan hasil bahwa perangkat yang dihasilkan praktis dan efektif, yakni hasil pengamatan keterlaksanaan pembelajaran yang mendapatkan skor 91.00 , pemerolehan respon positif mahasiswa terhadap semua aspek berada di atas $50 \%$, serta nilai rata-rata hasil tes pertama dan kedua meningkat dari 84.43 menjadi 94.49.

Perangkat pembelajaran yang dihasilkan ini baru sampai pada tahap pengembangan, belum sampai pada tahap desseminate (penyebaran). Untuk mengetahui keefektifannya, disarankan untuk mengimplementasikan perangkat pembelajaran ini pada ruang lingkup yang lebih luas.

\section{DAFTAR PUSTAKA}

Ernest, P. (1991). The Philosophy of Mathematics Education. Hampshire: The Falmer Press.

Fakultas MIPA. (n.d.). Retrieved from http://unnes.ac.id: http://mipa.unnes.ac.id

Hamzah, M. (2008). Efektivitas Pembelajaran Matematika Berbasis Teknologi Berbantuan CD Interaktif Berorientasi Model Kooperatif Tipe STAD pada Materi Bangun Ruang Kelas IX. Semarang: Universitas Negeri Semarang.

Handoyo, E., \& Tijan. (2010). Model Pendidikan Karakter Berbasis Konservasi: Pengalaman Universitas Negeri Semarang. Semarang: Universitas Negeri Semarang.

Hers, R. (1997). What is Mathematics, Really? London: Jonathan Cape.

Hidayat, M. A. (2004). Teori-teori Belajar Matematika. Jakarta: Departemen Pendidikan Nasional.

Johnson, D. W., Johnson, R. T., \& Smith, K. A. (1989). Active Learning: Cooperation in The College Classroom Intersection. Edina, Minnesota: Interaction Book Company.
Jones, M. G., \& Brader-Araje, L. (2002). The Impact of Constructivism on Education: Language, Discourse, and Meaning. American Communication Journal, 5(3).

Jurusan Matematika. (n.d.). Retrieved from http://unnes. ac.id: http://matematika.unnes.ac.id

Khabibah, S. (2006). Pengembangan Model Pembelajaran Matematika dengan Soal Terbuka untuk Meningkatkan Kreativitas Siswa Sekolah Dasar. Disertasi Universitas Negeri Surabaya.

Koch, R. (1999). Metaphysical Crisis and the Post-modern Condition. International Philosophycal Quarterly, 39(154), 39.

Marwanto, R. (2008). Keefektifan Pembelajaran Matematika dengan Strategi Kooperatif Tipe STAD Berbantuan CD Pembelajaran pada Materi Geometri Kelas VIII. Thesis Universitas Negeri Semarang.

Nykos, M., \& Hashimoto, R. (1997). Constructivist Theory Applied to Collaborative Learning in Teacher Education. The Modern Language Journal, 81(4), 506-517.

Poespowardojo, T. S., \& Seran, A. (2015). Filsafat Ilmu Pengetahuan: Hakikat Ilmu Pengetahuan, Kritik terhadap Positivisme Logis, serta Implikasinya. Jakarta: Penerbit Buku Kompas.

Slavin, R. E. (1995). Cooperative Learning, Theory and Practice 4th edition. Boston: Allyn and Bacon Publishers.

Slavin, R. E. (2008). Cooperative Learning . (N. Yusron, Trans.) Bandung: Nusa Media.

Suharsaputra, U. (2004). Filsafat Ilmu. Kuningan: Universitas Kuningan.

Suherman, E., Turmudi, Suryadi, D., Herman, T., Suhendra, Prabawanto, S., . . Rohayati, A. (2001). Strategi Pembelajaran Matematika Kontemporer. Bandung: Universitas Pendidikan Indonesia.

Sulistyorini. (1998). Pengembangan Belajar Pembelajaran dengan Model "Flex Your Brain" pada Pembelajaran Biologi untuk Meningkatkan Kemampuan Berpikir Kognisi dan Meta Kognisi. Thesis, IKIP Surabaya, Pascasarjana.

Suminar, E. P. (2011). Eksperimentasi Pembelajaran Matematika dengan Problem Based Learning dan Cooperative Learning Tipe STAD Ditinjau dari Gaya Belajar Siswa. Thesis Universitas Sebelas Maret.

Suyitno, H. (2014). Pengenalan Filsafat Matematika. Semarang: Universitas Negeri Semarang.

Thiagarajan, S., Semmel, D. S., \& Semmel, M. I. (1974). Instructional Development for Training Teachers of Expectional Children. Minneapolis, Minnesota: Leadership Training Institute/Special Education, University of Minnesota.

Tim Penyusun KKBI. (2008). Kamus Besar Bahasa Indonesia. Jakarta: Pusat Bahasa Depdiknas.

van den Akker, J., Branch, R. M., Gustafson, K., Nieveen, N., \& Plomp, T. (1999). Design Approaches and Tools in Education and Training. Netherlands: Springer . 